\section{Isolation and Identification of 1-Deoxy-1-(L-asparagino)-D-fructose \\ Formed in the Autoclaved Culture Medium}

\author{
Yuhzoh MiUra, Satoshi TaHara \\ and Junya MizUTANI
}

\section{Department of Agricultural Chemistry, Faculty of Agriculture, Hokkaido University, Sapporo, Japan}

Received June 16, 1973

In the cultivation of red-colored yeast, Sporobolomyces odorus AHU 3246, the growth of the yeast was stimulated when the synthetic medium was autoclaved for moderately long period. The analogous observation was also found between the autoclaved medium and the aseptically filtered medium. Such a phenomenon was generally found during the incubation of various microorganisms. ${ }^{11}$ Stimulation of initial growth of microorganisms was thought to be caused by the variation of components in the autoclaved culture solution. In connection with this heat activation effect many effective substances were identified to date, for example, the degradation products of sugars,,$^{2-41}$ ascorbic acid ${ }^{51}$ glucosylglycine $e^{6 !}$ etc. The authors are interested in the formation of new nitrogen containing compounds, especially ninhydrin positive substances in the autoclaved culture medium and this paper deals with isolation and identification of these compounds.

The following medium was employed: $10 \% \mathrm{D}$ glucose, $0.25 \%$ L-asparagine, $0.3 \% \quad \mathrm{MgSO}_{4} \cdot 7 \mathrm{H}_{2} \mathrm{O}$, $0.1 \% \mathrm{KH}_{2} \mathrm{PO}_{4}, 0.01 \% \mathrm{CaCl}_{2}$ and deionized water, pH 6.0.

After the medium was autoclaved, four ninhydrin positive spots appeared on the thin layer chromatogram, and two of them revealed color reaction of sugar. Fractionation of ninhydrin positive substances was performed as follows. Six liters of the autoclaved medium (at $120^{\circ} \mathrm{C}$ for $30 \mathrm{~min}$ ) was concentrated and treated with cation exchange resin. The eluate with $2 \mathrm{~N}$ aqueous ammonia or $0.5 \mathrm{~N}$ trichloroacetic acid was evaporated to dryness in vacuo and the residue was dissolved in $70 \%$ ethanol. Insoluble material (about $12 \mathrm{~g}$ ) was found to be L-asparagine added as a nitrogen source, and the filtrate was applied to a cellulose powder column $(4.5 \times 59 \mathrm{~cm})$, which was eluted and fractionated with solvents of $n$-butanol-acetic acid-water (4:1:1, $v / v)$ (solvent 1) and then $70 \%$ ethanol (solvent 2). From the fractions eluted with solvent $1,234 \mathrm{mg}$ of crystals were isolated purely. Both the crystals thus obtained and an authentic sample of L-aspartic acid showed identical spots on TLC with solvent $1(R f=$ 0.180 ), and the same absorption bands on IR spectroscopy. Anal. Found: C, 35.62; H, 5.26; N, 10.59\%. Calcd. for $\mathrm{C}_{4} \mathrm{H}_{7} \mathrm{NO}_{4}$ : C, $36.09 ; \mathrm{H}, 5.30 ; \mathrm{N}, 10.52 \%$.

The column was washed with solvent 2 after the elution with 3 liters of solvent 1 . From 2 liters of washings $70 \mathrm{mg}$ of white powder was isolated. This substance showed both ninhydrin positive reaction and ketose positive reaction with naphthoresorcinolphosphoric acid reagent. Therefore, this compound was estimated to be 1-deoxy-1-(L-asparagino)-D-fructose (fructose-asparagine). As it was a new compound, ${ }^{81}$ fructose-asparagine was prepared by the method of condensation of $\mathrm{D}$-glucose with L-asparagine in anhydrous methanol. ${ }^{71}$ Both the crystals isolated and the synthetic sample showed identical spots on TLC with the following solvent system: phenol-water $(4: 1, v / v)$, $R f=0.47$; solvent $1, R f=0.04$; pyridine-isoamyl alcoholwater $(7: 7: 6, v / v), R f=0.05$. IR spectra of both

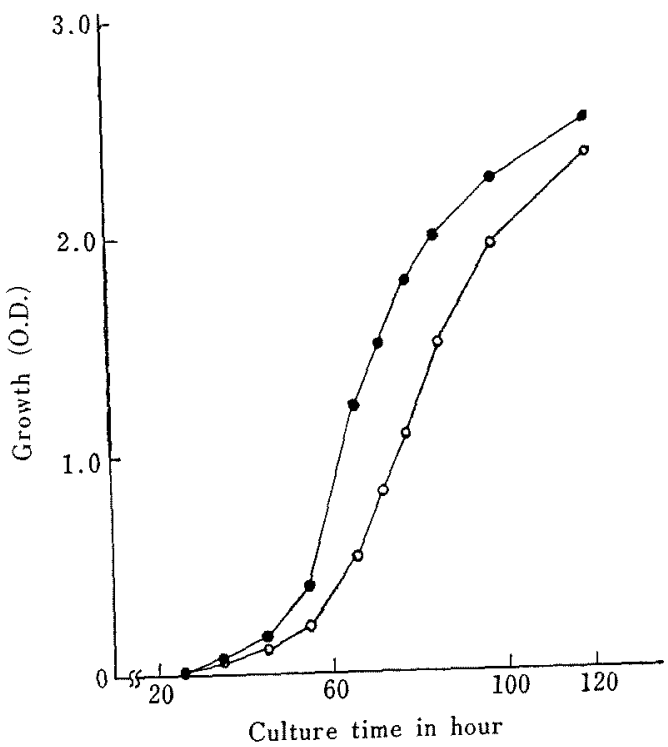

FIG. 1. Effect of Fructose-Asparagine Added to the Medium on the Growth of S. odorts.

Fructose-asparagine was added to the medium by $100 \mu \mathrm{g} / \mathrm{ml}$. The yeast was cultured in $500 \mathrm{ml}$ shaking flasks containing $150 \mathrm{ml}$ of the media at $25^{\circ} \mathrm{C}$ on a reciprocal shaker. Growth of the yeast, average of 5 flasks was measured colorimetrically (O.D. at $660 \mathrm{~nm}$.$) .$

$0-0$, Medium without the nitrogen source autoclaved at $120^{\circ} \mathrm{C}$ for $15 \mathrm{~min}$ and L-asparagine added aseptically.

- Medium without nitrogen source autoclaved, and $\mathrm{L}$-asparagine and fructose-asparagine added aseptically. 
samples were identical with each other. $\nu_{\mathrm{max}}^{\mathrm{KBr}} \mathrm{cm}^{-1}$ : $\left.3500 \sim 3100(\mathrm{OH}), 2700 \sim 2250 \mathrm{O} \stackrel{\oplus}{\mathrm{N}} \mathrm{H}_{2}\right), 1680\left(\mathrm{CONH}_{2}\right)$, $1625\left(\mathrm{COO}^{\ominus}\right)$. Anal. Found for the isolated compound : $\mathrm{C}, 40.03 ; \mathrm{H}, 6.29 \%$. Found for the synthesized fructose-asparagine: $\mathrm{C}, 39.91 ; \mathrm{H}, 6.59 \%$. Calcd. for $\mathrm{C}_{10} \mathrm{H}_{18} \mathrm{~N}_{2} \mathrm{O}_{8} \cdot 1 / 2 \mathrm{H}_{2} \mathrm{O}: \mathrm{C}, 39.61 ; \mathrm{H}, 6.33 \%$. [a] $]_{\mathrm{D}}^{16}$ for the isolated compound $-38^{\circ}$ and for the synthesized fructose-asparagine, $-40^{\circ} \quad(c=1$, water $)$, mp of both compounds $124 \sim 125^{\circ} \mathrm{C}$ (decomp.).

Another ninhydrin positive component which gave color reactions of sugar was not identified.

Effect of fructose-asparagine $(100 \mu \mathrm{g} / \mathrm{ml}$ medium) on the growth of the yeast is shown in Fig. 1. Fructoseasparagine affected on the initial growth of the yeast rather than its logarithmic phase.

In case of the incubation of $S$. roseus AHU 3980 more distinct additive effect was observed. For example, after $71 \mathrm{hr}$ incubation the O.D. value was 0.898 for the fructose-asparagine added medium and 0.161 for the blank. L-Aspartic acid also exhibited the additive effect.

We believe that the heat activation effect will ascribe to the formation of various compounds by autoclaving the medium and though the mechanism may not be simple, the sugar-amino acid condensation product, fructose-asparagine, isolated for the first time in th work, is one of the effective substances.

\section{REFERENCES}

1) B. M. Guirard, Ann. Rev. Microbiol., 12, 24 (1958).

2) K. L. Smiley, C. F. Niven, Jr. and J. M. Shermar Bacteriol., 45, 445 (1943).

3) J. E. Auclair and A. Portmann, Nature, 179, 78 (1957).

4) E. E. Snell, E. Kitay and E. Hoff-J $\phi$ rgenser Arch. Biochem., 18, 495 (1948).

5) J. C. Rabinowitz and E. E. Snell, J. Biol. Chem. 69, 631 (1947).

6) M. F. Field and H. C. Lichstein, J. Bacteriol. 76, 485 (1958).

7) A. Abrams, P. Lowy and H. Borsook, J. Amer Chem. Soc., 77, 4794 (1955); K. Heyns and H Paulsen, Ann., 622, 160 (1959).

8) Recently the isolation of this compound fron flue-cured tobacco leaves has been published ir this journal. K. Yamamoto and M. Noguchi. Agr. Biol. Chem., 37, 2185 (1973). 